\title{
LYPD3 wt Allele
}

National Cancer Institute

\section{Source}

National Cancer Institute. LYPD3 wt Allele. NCI Thesaurus. Code C132241.

Human LYPD3 wild-type allele is located in the vicinity of $19 q 13.31$ and is approximately 5 $\mathrm{kb}$ in length. This allele, which encodes Ly6/PLAUR domain-containing protein 3, plays a role in cell-matrix interactions. 